\title{
Restoration of ancient bronze bells. Part I: powder metallurgy
}

\author{
Restauración de antiguas campanas de bronce. Parte I: pulvimetalurgia \\ Ernesto Ponce L. ${ }^{1} \quad$ José de la Vega ${ }^{1}$ \\ Recibido 17 de abril de 2014, aceptado 25 de junio de 2014 \\ Received: April 17, 2014 Accepted: June 25, 2014
}

\begin{abstract}
There is a big number of church bells from the Colonial Period in the highlands of Northern Chile, which are damaged by use during centuries and by falls due to earthquakes that periodically affect the region. The aim of this work was to create a non-invasive method to restore these valuable pieces, leaving minimum trace of repair. A fissured church bell from the late nineteenth century was restored. Powder metallurgy was used to repair only in the thin line of the crack, and to prevent coarse material removal action on both sides of the crack, with subsequent filling with conventional weld at high temperatures. Fissures were filled with copper and tin powder, which were then welded with tin at a low temperature. The advantage of this method is that it does not cause local heating that can brittle the vicinity of the welded area, resulting in a smooth joint and a good adhesion surface for good sound transmission that can withstand stresses. Results: In order to verify the efficiency of the method, joint material strength was measured, and the sound was compared to the dominant note required by the DIN4178 Standard. A finite element model incorporating a filler ring in the repair area was as well verified. The rationale for these repair works lies in that the old bells in question need to be preserved, since they are culturally valuable artifacts that hold rich metallurgical knowledge and are part of the national heritage.
\end{abstract}

Keywords: Metallurgy restoration, powder metallurgy, ancient metallurgy, bells, bronze welding, finite elements, crack repair.

\section{RESUMEN}

Existe una gran cantidad de campanas del período colonial pertenecientes a iglesias del Altiplano del Norte chileno, que se encuentran dañadas por el uso durante siglos y por caídas debido a los sismos que periódicamente afectan la región. El objetivo fue crear un método no invasivo para restaurar estas valiosas piezas, dejando un mínimo rastro de la reparación. Se restauró una campana de iglesia de fines del siglo XIX que estaba agrietada. Se empleó metalurgia de polvos para reparar solo en la delgada línea de la fisura y evitar la invasiva acción de extraer material en ambos lados de la grieta, con el posterior relleno con soldaduras convencionales a temperaturas mayores. Se rellenaron las fisuras con cobre y estaño en polvo que luego se soldó con estaño, a baja temperatura. Las ventajas del método radican en no producir un calentamiento local que fragilice la vecindad de la soldadura, dar una unión de superficie lisa de gran adherencia que da una buena transmisión del sonido y capaz de soportar tensiones. Resultados: Para comprobar su eficiencia se midió la resistencia del material de la unión, también se comparó el sonido con la nota dominante que debió tener la campana según Norma DIN 4178. Otra verificación fue un modelo de elementos finitos que incorpora un anillo de material de aporte en el sector de la reparación. Se justifican estos trabajos porque las campanas necesitan ser conservadas, ya que encierran una gran riqueza cultural y conocimientos metalúrgicos que son patrimonio de la nación.

Palabras clave: Restauración metalúrgica, pulvimetalurgia, metalurgia antigua, campanas, soldadura para bronce, elementos finitos, reparación de grietas.

1 Escuela Universitaria de Ingeniería Mecánica. Universidad de Tarapacá. Casilla 6-D. Arica, Chile. E-mail: eponce@uta.cl; josedelavega@arkos.cl 


\section{INTRODUCTION}

In order to convert the colonies in the Americas into Catholicism, a big number of churches were erected since the end of the 16th century. This occurred as well in the highlands and foothills in the northernmost part Chile. Many colonial churches and bells can still be found in this area. They have survived use and earthquakes for centuries. The architecture by then was a combination of Spanish 16th-17th century style and local materials and indigenous labor. In Northern Chile, indigenous peoples still appreciate their churches and bell towers, since they are integral part of the local culture. Churches and their bell towers were once part of their lives, with religious festivals, processions and rites still happening there. Bells were very important to call for the parishioners to come to celebrations and to mass. According to the Catholic tradition, the size of bells was in accordance with the number of inhabitants in a village or town; e.g. for a 5,000 inhabitant town, a bell required to have a weight of approximately $1,000 \mathrm{~kg}$ [1]. Each tower bell had more than one bell, a big one and other small ones that were used for everyday services.

Casting techniques were based on European technologies, but there were not fixed patterns for geometry, except in some cases. They were placed in a mold with a clay and sand mix (some remains can still be found to be attached to the bell bends). The mold consisted of an internal nucleus made in a horizontal lathe, and an external layer. An empty space was left between the two molds. The axis of the bell was kept in vertical position on a horizontal platform made of abode and mortar. Molten metal was poured from an upper open through on the external mold. On the upper part, below the open trough, there were handles to hold the finished piece in the bell tower. The open trough allowed for the metal to contract while solidifying, without affecting the handles. In most of the pieces under study, the wall thickness is greater than that of European bells, but external dimensions are similar.

The main smelter would not engrave his name on the bell, but did engrave the casting date and some other inscriptions in some exceptional cases. Some finishes were neither classic nor done by chisellers, which shows that the bells were built by local smelters. However, many of the bells show no cracks, which is evidence of their creators' knowledge of metallurgy. It is worth noting that a European bell is estimated to last for half a century, whereas bells found in the highlands have already had a life of over four centuries. No information is available on the smelters or those who financed the works.

Common alloys of the time contained approximately $78 \%$ copper and $22 \%$ tin. The use of lead and zinc was avoided because it affected the quality of sound. Nevertheless, old literature indicates a weight ratio as follows: 79 parts of copper, 23 parts of tin, and 6 parts of zinc, totalling 108 parts. Other smelters were more conservative and included only $2 \%$ zinc, with $78 \%$ copper and $20 \%$ tin. Zinc was called Indian tin and became known in Europe after the 12 th century. At the beginning of the 12th century, it was proved that gold and silver did not improve the quality of sound, contrary to the thought of the time. These noble metals have not been detected in analyses of ancient bell bronze. It could have possibly been a smelters' resort to keep the precious metal for themselves, since it was difficult to carry out reliable metallurgy analysis by that time.

Cracks on the bell walls were caused by the strikes of the clapper, which create compression waves that expand through the metal. In the wall thickness considered, when reaching the opposite surface, waves are reflected inverted as traction waves [2]. Non-centrifuged old bronze withstands compression better than stress, because it is a more fragile material. This is why the crack starts near the external surface of the bell, even though the clapper has struck the inside wall. When vibrations are produced by strikes, the material is submitted to cyclic loads that cause material fatigue. Once a crack has occurred, it grows rapidly because stresses at the bottom of the fissure are proportional to the inverse of the square of its bend radius. The smaller the radius is, the higher the stresses at that point are. For a homogenous, impurityfree piece of material with no residual stresses, the stresses under the area of clapper strike are (for a conventional circular-arc profile church bell): parallel to the axis of the bell $=11.014 \mathrm{P}$, transverse to the bell axis $=4.333 \mathrm{P}, \mathrm{P}$ being the impact stress. This formulation resulted from [3], and geometry was obtained from [4]. This suggests that longitudinal fissures prevail but not in all cases. When a bell is smelted and poured from its upper part at a low flow speed, smelting layers that cool down at different 
temperatures and speeds are created. This creates texture differences at the different horizontal levels, with material mechanical properties and residual stresses not being homogenous. Differences in these levels may facilitate the occurrence of fissures transverse to the axis of the bell. This can also be observed in ancient cast iron cannons rescued from the ocean in which corrosion is visible in transversal smelting layers with the configuration of a "millefeuille cake". The pieces were smelted vertically and buried in the ground, with the same cooling speed problems as those of a big bell.

The life of European bell is around 50 years [5]. Its classic composition is $75 \% \mathrm{Cu}-25 \% \mathrm{Sn}$ and $79 \% \mathrm{Cu}-21 \% \mathrm{Sn},[6-8]$. They are hard, "file-resistant" alloys of a great sound quality which are in turn easily brittled.

Conventional welding repair with electrical equipment or with a combination of gases such as oxyacetylene or oxybutane is difficult, since there is not always compatibility between the filler material and the piece material, even if they are both copper-based. Another effect of high-heat welding is loss of Sn or $\mathrm{Zn}$ in the areas around the fusion, which weakens the contours with temperatures of over $800{ }^{\circ} \mathrm{C}$ for the process to be efficient. Powder metallurgy repair is a non-invasive alternative which is more economical and leaves no repair trace, and does not weaken the material given that temperatures are around $300{ }^{\circ} \mathrm{C}$.

In cases of fall by an earthquake, as in Figure 1, bells tend to fall to the tower floor, which is generally made of stone. Bells tend to deform and their slope usually becomes damaged by the impact, as in Figure 2. The beauty of some of bells justifies restoration, as in Figure 3.

The objective of this work is to repair cracks bronze bells through powder metallurgy.

\section{METHOD}

A fissured church bell from the late 19th century was restored, which is in no use due to a crack transverse to the axis. The fissure extends along the slope of the bell in most of the circular perimeter of the clapper strike. Given the nature of the fissures and the aesthetic complications of electrical or oxyethylene

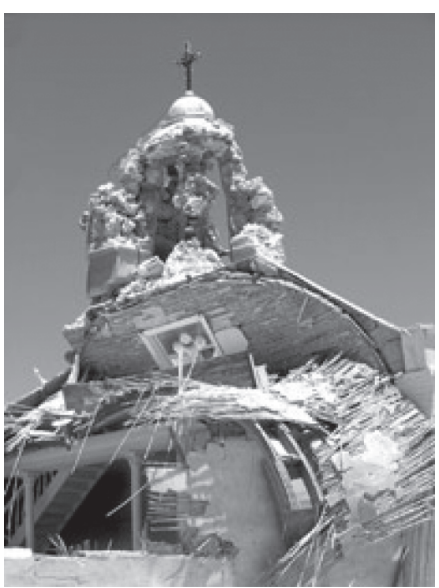

Figure 1. Bell tower in Northern Chile collapsed by an earthquake in 2005 .

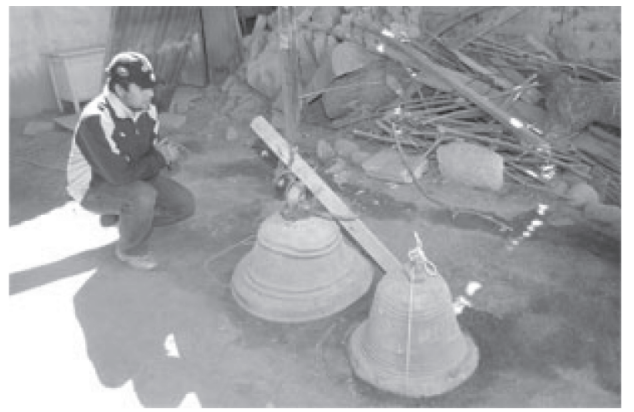

Figure 2. Bells collapsed by an earthquake in 2005.

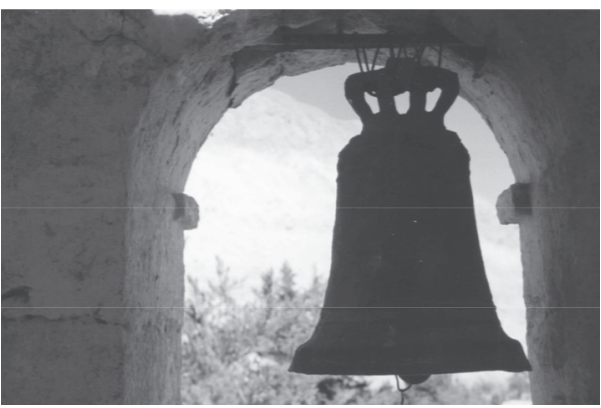

Figure 3. Bell found in Northern Chile.

welding, filling the separation with powder copper with an ASTM 100 mesh was preferred. The fusion matrix was tin molten with a small butane torch that creates fusion at low temperatures. The advantage of this method lies in that it does not cause local heating that leads to volatilization of some elements, preventing weakening of the area surrounding the fusion. There is no weld bead but a filling with a homogenous, good-adhesion material that allows for good sound transmission and can withstand stresses. 
In order to verify the efficiency of the method, joint material strength was measured, and the sound was compared to the dominant from factory note. A finite element model incorporating a filler ring in the repair area was as well theoretically verified. The crack repair by powder metallurgy was tested with penetrant liquid. In test no cracks appeared.

\section{THEORETICAL ANALYSIS}

In an elastic solid material such as the bronze of a bell, disturbance produced by the strike of a clapper causes two deformation modes: A longitudinal compression wave (or traction wave as reflected on the opposite wall) that causes a change in volume associated to compressive or extension stresses, and a transverse wave that creates cut distortions and shear stresses. Studies [2] indicate that in a theoretical medium of infinite extension, wave propagation speed is given by:

longitudinal speed: $C l=\sqrt{E / d}$

transverse speed: $C t=\sqrt{G / d}$

where: $\mathrm{E}$ is the modulus of elasticity in psi, $\mathrm{G}$ is the shear modulus in psi, and $\mathrm{d}$ is the density in slug/ $/ \mathrm{ft}^{3}$.

The above results in the following wave speeds in $\mathrm{ft} / \mathrm{s}$ :

Table 1. Transverse speed, longitudinal speed, and density of different metals [2] *.

\begin{tabular}{|l|c|c|c|}
\hline \multicolumn{1}{|c|}{ Metal } & Cl & Ct & d \\
\hline bronze & 14100 & 6700 & 17.13 \\
\hline copper & 14900 & 7400 & 17.29 \\
\hline lead & 7100 & 2300 & 21.93 \\
\hline Tin & 9500 & 4800 & 14.10 \\
\hline
\end{tabular}

*In original units.

For speed $\mathrm{V}$ of a particle, longitudinal stresses are:

$$
\sigma=d \cdot C l \cdot V
$$

and transverse or cut stresses would be:

$$
\tau=d \cdot C t \cdot V
$$

In order to compare the effects on different metals and considering speed $\mathrm{V}=1 \mathrm{ft} / \mathrm{s}$, the stresses would be as follows:
Table 2. Longitudinal and cut stresses in psi [2].*

\begin{tabular}{|l|c|c|}
\hline \multicolumn{1}{|c|}{ Metal } & Longitudinal & Cut \\
\hline bronze & 1610 & 765 \\
\hline copper & 1785 & 885 \\
\hline lead & 1080 & 350 \\
\hline tin & 930 & 470 \\
\hline
\end{tabular}

*In original units.

It can be observed that when interposing a material with wave transmission speed faster than that of bronze, such as tin, strike stresses would be reduced, Sn fusion being therefore more resistant than bronze.

A further study should consider where the bell is struck and the $\mathrm{V}$ speed produced by the clapper strike. Resulting stresses will depend on the magnitude of the strike. This $\mathrm{V}$ speed would be a function of the piece hardness, and should be associated with the bronze deformation and impact duration time. This goes beyond the scope of this paper; therefore, a modest computational model was carried out, with the geometric and mechanical properties of a bell, in order to visualize the map of the stresses caused by striking the piece with a $408 \mathrm{~N}$ force, corresponding to the strike of a 4-kg clapper at a speed of $1 \mathrm{~m} / \mathrm{s}$ (for an impact time of $0.01 \mathrm{~s}$ ). Force was calculated by impulse and conservation of momentum. Normal strikes have half of the force simulated in this model.

A model of stress in an elastic medium, computed with ALGOR (now Autodesk) finite element software package, which includes a $\mathrm{Cu}-\mathrm{Sn}$ repair ring, is shown in Figures 4, 5, and 6. Input data represent density and modulus of elasticity of the materials involved. The clapper is simulated striking from the inside of the piece with a force of $408 \mathrm{~N}$. Usual impact forces tend to be lower than that measure. Predictions are Von Mises stresses in $\mathrm{N} / \mathrm{m}^{2}$. Conditions at the edge were calculated considering free rotation in the dome central nodes in the same direction as the strike, simulating the piece hanging from the upper base. The geometry of the bell was taken from the actual model. The model used 2160 3D elements brick type, 8 nodes per element. The filled crack used 120 small elements (for greater precision). Three meshes were tested, leaving us with the most accurate.

\section{METHODOLOGY}

Fissures were cleaned with hydrochloric acid $(\mathrm{HCl}$ $+\mathrm{H}_{2} \mathrm{SO}_{4}$ ). After chemical cleaning, the repair area 


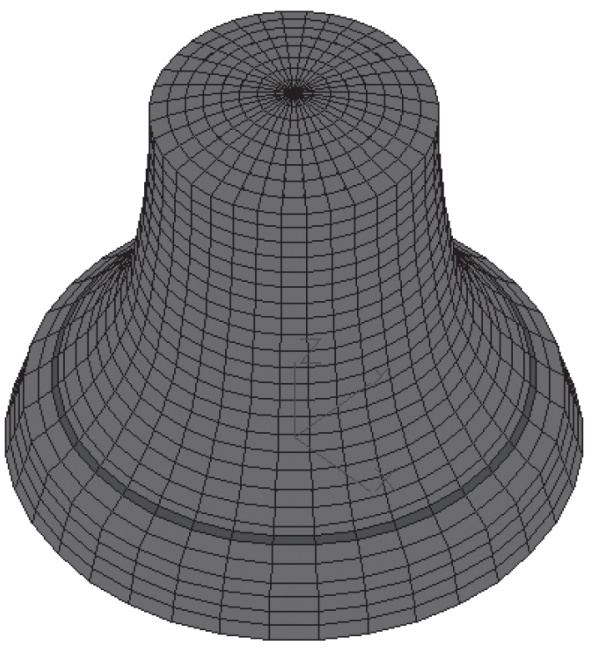

Figure 4. Bell model with a $\mathrm{Cu}-\mathrm{Sn}$ repair ring.

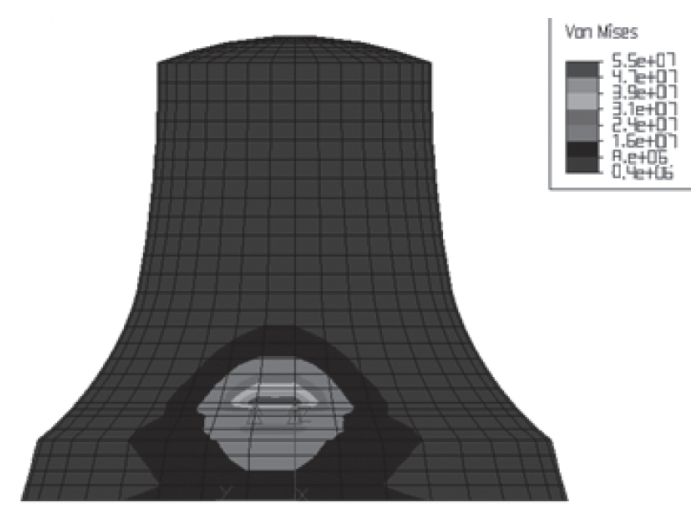

Figure 5. Lateral view showing external stresses of the bell when receiving the clapper strike with a force of $408 \mathrm{~N}$. Stresses are in $\mathrm{N} / \mathrm{m} 2$.

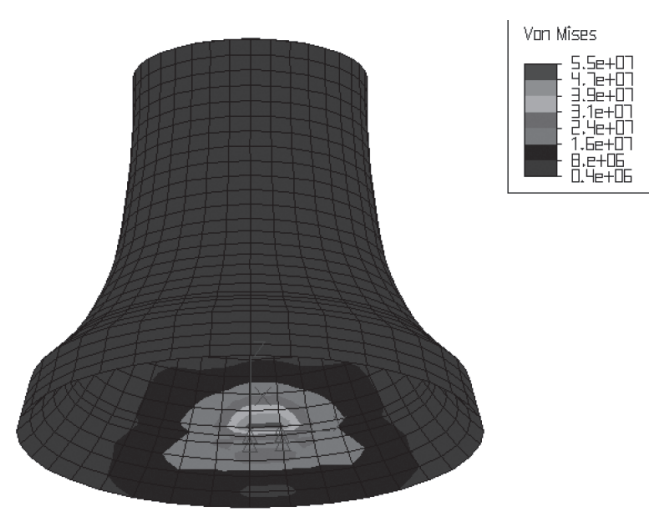

Figure 6. Interior view of the bell indicating the stress map when receiving the $408 \mathrm{~N}$ clapper strike. Stresses are in N/m2. was heated with a butane torch, and the crack surface was then covered with a thin Sn layer (when tinplated, the crack is still open). The opening was filled manually with powder metal, making sure penetration was appropriate by slightly striking or causing small vibrations in the repair area. The aim of this was to refill the separations with powder $\mathrm{Cu}$ or brass, adding powder $\mathrm{Sn}$ of the same dimension as the mesh. Metal with higher melting points were $\mathrm{Cu}$ and powder Brass, as tested in separate trials. Once the opening was refilled in one sector, the torch flame was applied to smelt the Sn powder and adhere it to the $\mathrm{Cu}$ powder. Afterwards, the joint was sealed with a Sn layer and the powder mix so as to completely cover the crack. No paint stripper was applied to $\mathrm{Cu}$ but to brass. Mixing used was $75 \%$ for $\mathrm{Cu}$ or Brass, and $25 \%$ for $\mathrm{Sn}$.

Restoration is reversible and can be eliminated with a butane torch or an equivalent tool if a better method is to be used in the future.

Figures 7, 8 and 9 represent the bell before the welding process.

Figure 7 shows the crack that surrounds the slope of the bell, and that is found behind the area of clapper striking, forming a line around the perimeter.

Figure 8 is an amplification of the external area of the bell, the crack having a dimension of around $1 \mathrm{~mm}$.

Figure 9 shows the internal side, the area of the clapper strike, where the crack measures less than $1 \mathrm{~mm}$.

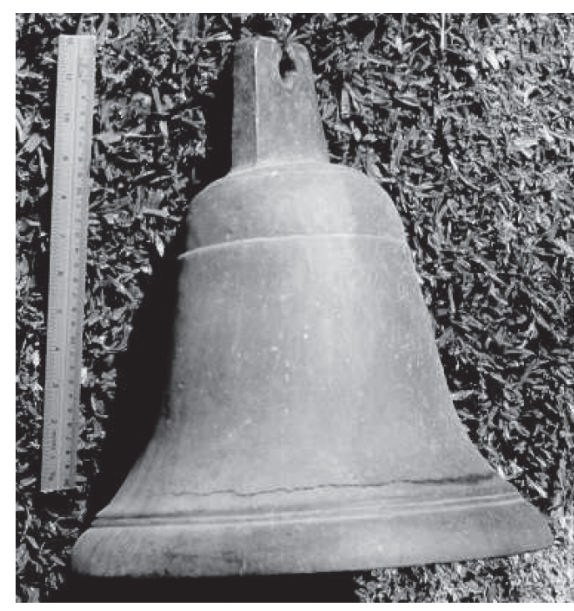

Figure 7. Fissured church bell. 


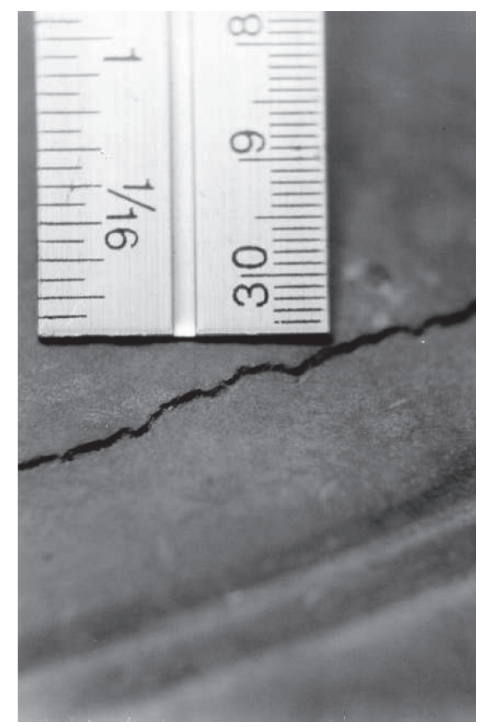

Figure 8. External side of a transverse crack.

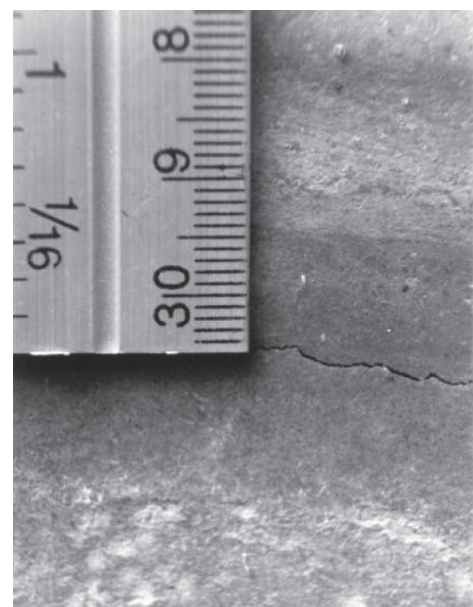

Figure 9. Internal side of a through-wall crack. The wear caused by the clapper can be observed.

\section{RESULTS}

Compression trials: Uncompacted powder metals were smelted in small cylindrical molds in order to reproduce the filling of the crack without previous metallurgy compression. Trials of the powder metal mix with extra Sn weld were carried out compressing cylinders of diameter $=$ height $=8$ in a universal trial machine from Adamel, France, with a capacity for $2000 \mathrm{~kg}$. A summary of the welding trials by powder metallurgy is in Tables 3 and 4 .
Table 3. Use of electrolyte powder copper and powder tin.

\begin{tabular}{|l|l|l|l|l|}
\hline $\begin{array}{l}\text { ASTM } \\
\mathbf{N}^{\circ}\end{array}$ & $\begin{array}{l}\text { Sn } \\
\text { powder } \\
\text { joint; } \\
\text { untinned } \\
\text { crack }\end{array}$ & $\begin{array}{l}\text { Sn } \\
\text { powder } \\
\text { joint; } \\
\text { tinplated } \\
\text { crack }\end{array}$ & $\begin{array}{l}\text { Uncompacted } \\
\text { filling-based } \\
\text { observation }\end{array}$ & $\begin{array}{l}\text { Stress } \\
\text { measured } \\
\text { in } \mathbf{~ k g} / \mathbf{c m}^{2}\end{array}$ \\
\hline 100 & good & superior & Best space filling & 1018 \\
\hline 60 & good & good & $\begin{array}{l}\text { Incomplete } \\
\text { filling }\end{array}$ & 902 \\
\hline 35 & good & good & $\begin{array}{l}\text { Worst space } \\
\text { filling }\end{array}$ & 856 \\
\hline
\end{tabular}

Table 4. Use of Cu70-Zn30 powder Brass and powder Sn.

\begin{tabular}{|l|l|l|l|l|}
\hline $\begin{array}{l}\text { ASTM } \\
\text { Mesh } N^{\circ}\end{array}$ & $\begin{array}{l}\text { Untinned } \\
\text { crack joint }\end{array}$ & $\begin{array}{l}\text { Tin-plated } \\
\text { crack fusion }\end{array}$ & Effect observed & $\begin{array}{l}\text { Stress } \\
\text { measured in } \\
\mathrm{kg} / \mathrm{cm}^{2}\end{array}$ \\
\hline 100 & Bad & regular & $\begin{array}{l}\text { Salts are produced } \\
\text { when cleaning } \\
\text { with acid }\end{array}$ & 701 \\
\hline 60 & Bad & Bad & $\begin{array}{l}\text { Same as previous } \\
\text { and incomplete } \\
\text { filling }\end{array}$ & 643 \\
\hline 35 & Bad & Bad & $\begin{array}{l}\text { Worse than } \\
\text { previous }\end{array}$ & 605 \\
\hline
\end{tabular}

Figure 10 shows repair of the crack with powder metallurgy welding; no polishing. ASTM 100-mesh $\mathrm{Cu}$ powder and powder $\mathrm{Sn}$ were used. The crack was previously cleaned with acid and then tin-plated, the two sides of the crack being separated from each other. The crack was filled with the powder mix to be then fused with a butane torch. Figure 11 shows the image of the piece polished and amplified; a thin scar signals restoration.

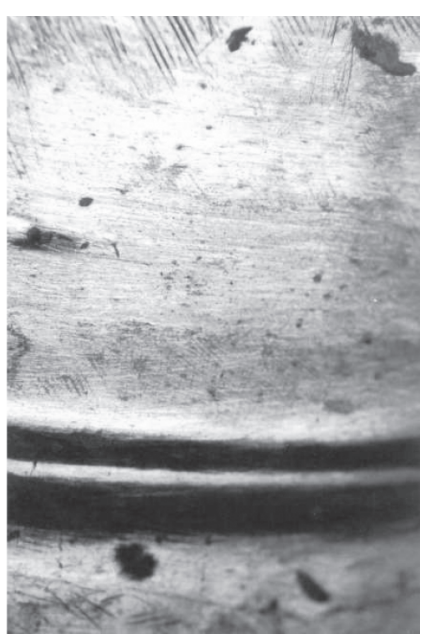

Figure 10. Restoration with molten powder $\mathrm{Cu}$ and $\mathrm{Sn}$. The remainings of external welding have not been polished yet. 


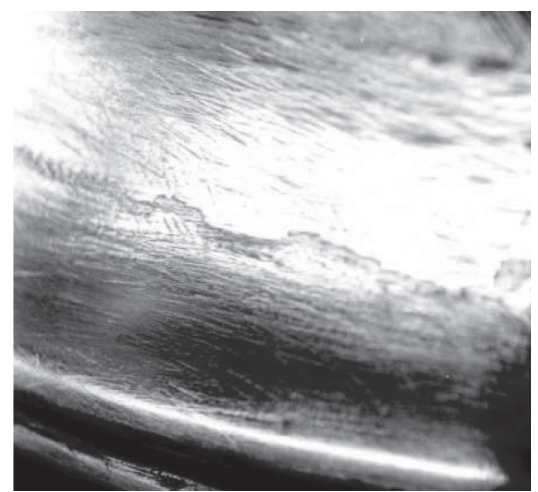

Figure 11. Amplified crack repair. The surface has been polished.

Micrographs: None of the 6 metallurgy samples were attached with chemical products, since it was not necessary given the good visualization achieved by the microscope. A 50X amplification was used in all cases to compare the different textures at the same scale.

Due to space reasons, only relevant micrographs are shown. Figures 12-14:

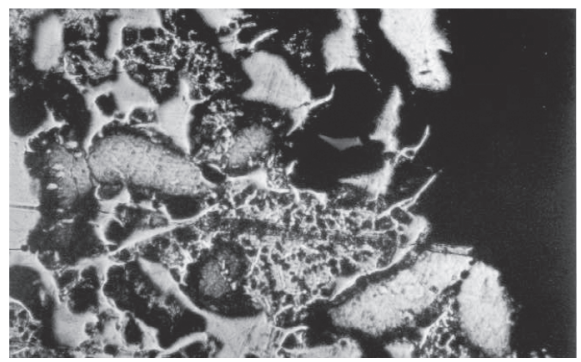

Figure 12. 100-mesh powder $\mathrm{Cu}$ and $\mathrm{Sn}$ mix. Incorrect joint is shown in big cavities (dark-colored right side). 50X amplification. Untinned crack contours. The edges of the crack were not tin-plated.

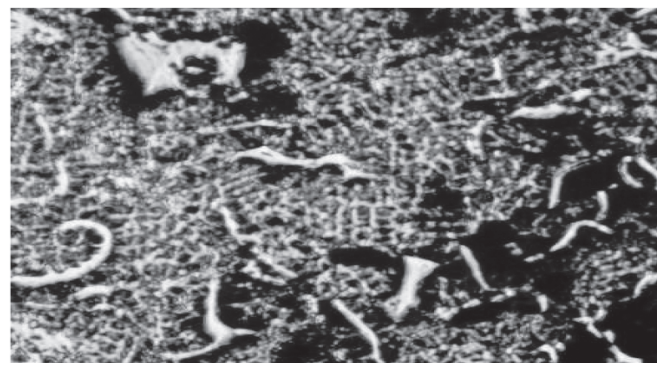

Figure 13.100-mesh Brass and powder Sn, and Sn welding. The big number of darkcolored impurities creates a bad joint. 50X amplification.

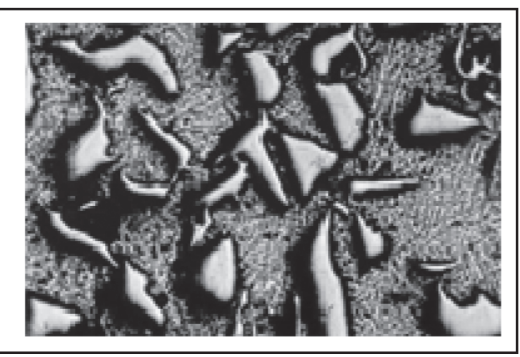

Figure 14.60-mesh $\mathrm{Cu}$ and $\mathrm{Sn}$, and $\mathrm{Sn}$ welding. 50X. Tin-plated crack. Good $\mathrm{Cu}$ anchors can be observed in the Sn matrix. 35mesh and 100-mesh copper micrographs are similar, except from the size of $\mathrm{Cu}$ particles.

Restoration of sound. In the Universidad de Tarapacá music room, the restored bell sound was compared to three calibrated pianos. The clapper initially produced a la \# tone that required correction. The bell was thus set to tone according to the DIN 4178 Standard (do 4), shortening the clapper longitude in $5.5 \mathrm{~mm}$. This was carried out by means of two threaded ends of the clapper axis, connected by a long nut and a lock nut.

Finite elements predicted a stress of $0.055 \mathrm{GN} / \mathrm{m}^{2}$ for a clapper impact of $408 \mathrm{~N}$. This stress is lower than the rupture stress in traction of commercial cast bronze $\left(0.37 \mathrm{GN} / \mathrm{m}^{2}\right)$.

\section{DISCUSSION AND CONCLUSION}

Fusions tried with a powder combination of $75 \%$ powder brass and $25 \%$ powder $\mathrm{Sn}$ failed due to formation of impurities when welding. When trying to apply the butane torch flame, a significant amount of slag was formed, and this prevented a good joint.

The best results were obtained with ASTM 100-mesh electrolyte copper and tin, with the crack previously cleaned and tin-plated, and $\mathrm{Sn}$ as weld. Since it created the best joint in the studied group and because of its smaller particle dimension $(0.149 \mathrm{~mm})$, ASTM 100-mesh $\mathrm{Cu}$ reached the interstices of the fissure. The smaller the powder metal particle dimension is, the better the results are. In through-wall cracks, welding can be applied on both sides. In single-open cracks, it is not easy to measure welding penetration, not even using ultrasound, since the palpation area covers a length bigger than the width of the fissure. 
Gammagraphic analysis was not available. Anyway liquid penetrant tests indicated no cracks.

The superficial finish was good, but it required rough grain sandpaper to remove excess sealing tin.

Micrographs of joints indicate the existence of material composed of a Sn matrix and Cu chips that creates an anchor in it. Brass is neither formed nor sintered powder metallurgy material.

The quality of the joint will depend on the degree of training of the person who carries out the work; nevertheless, an expert welder is not required.

Resistance of the fusion is lower than that of bronze, but it is enough to extend the useful lifetime of the piece. In order to do this, it not is necessary to move the clapper so that it strikes the repaired crack at a certain distance, unless a change of tone is wanted.

From factory bell tone was do 4 for a $350 \mathrm{~mm}$ diameter piece, weighing $0.20 \mathrm{kN}$, classified by the DIN 4178 Standard as a fine slope bell. The tone measured after repair for the initial clapper length (striking on the repaired zone) produced a la \# tone. Subsequently, it was calibrated shortening that length in $5.5 \mathrm{~mm}$, which was achieved with a long nut and lock nut threaded joint in the piece arm. Calibration was carried out at the Universidad de Tarapacá music room, using three pianos.

In this damaged piece, as well as in many others found in Northern Chile, the clapper was made of wrought iron, not of $\mathrm{Cu}$, bronze or grey cast iron. The useful lifetime of the bell was reduced due to higher hardness and lower relative deformation of the impact material.

Metallurgy restoration accomplished the expected results: simplicity, easy method reproduction, low temperature to prevent weakening of bronze in the edges, good mechanical resistance, and good sound transmission.

It is worth noting that if a more efficient repair method is created, powder metallurgy welding can be easily removed.

Finite-element modeling allowed predicting joint stresses for an impact load. These predictions seem reasonable, since the crack is created in the area of strike, as indicated in the model images. It is important to note that usual strikes have half the effect of the model; thus, in an elastic medium, stresses would be half of those calculated (both of them are lower than that of bronze rupture). Variations are not observed in the stresses of the (interior) strike area or in the external part of the bell wall. This might be due to the uncertainty in the model. In summary, it is predicted that the welding will resist, and this was subsequently verified.

Comparison with published work. Information has been sought on restoration of metals by powder metallurgy, in the 3rd [9] \& 4th Latin American Congress on Conservation and Restoration of Metals [10]. No information appears, neither in [11]. The method used is really new and nothing like it has been recently published.

This repair cracks in bronze bells is unique. The method indicated to fill the empty spaces by powders of copper and then join them with a tin matrix, gives a similar reinforcing like steel bars in concrete. However it does not apply to missing pieces larger than $3 \mathrm{~mm}$, because the metal powder is blew out of the crack, by the torch.

The described work is relevant because it allows restoration of a significant number of ancient fissured bells in the Chilean highlands and other regions, since they are culturally valuable artifacts that hold rich metallurgical knowledge and are part of the national heritage.

\section{ACKNOWLEDGEMENTS}

The Universidad de Tarapacá, the Convenio de Desempeño Internalización UTA project, and engineer Modesto Mollo and music teacher Gustavo Morales, who made this work possible.

\section{REFERENCES}

[1] E. Ponce, G. Foccaci y E. Quintana. "Campana fabricada en 1729 destinada a la ciudad de San Marcos de Arica". Revista Límite ${ }^{\circ} 2$, pp. 28-35.1995. ISSN: 07117-2338.

[2] ASTME. "High-Velocity Forming of Metals". E.J. Bruno, editor. Dearborn, Michigan. 1968. 
[3] Hütte. "Manual del Ingeniero". Academia Hütte de Berlín, cap. V: Envolventes y fondos de revolución, Gustavo Gili, Barcelona, España. 1965.

[4] T.D. Rossing and R. Perrin. "Vibrations of Bells". Applied Acoustics. Vol.20, pp. 41-70. 1987.

[5] Espasa. "Enciclopedia Universal". Campanas. Espasa Calpe, Madrid, España. 1958.

[6] J. Duponchelle. "Manual del Fundidor de Metales". 4a edición. Gustavo Gili. Barcelona, España. 1960.

[7] Cuerpo de Redacción Técnica del Bibliographisches Institut de Mannheim: "Enciclopedia Técnica Ilustrada". Planeta. Barcelona, España. 1969.
[8] A. Schülze. "Moldeo y fundición". Gustavo Gilli, editor. Barcelona, España. 1961.

[9] ICCROM 2009.3er Congreso Latinoamericano de Restauración de Metales. URL: http:// iccrom.org/eng/02info en/02 04pdf-pubs

[10] ICOM-CC 2011.IV Congreso Latinoamericano de Conservación y Restauración de Metales. URL: http://ipce.mcu.es/difusion/ publicaciones/monografias.html

[11] S. Martínez y E. García "Técnicas Metodológicas aplicadas a la ConservaciónRestauración del Patrimonio Metálico". Ministerio de Cultura. Madrid, España. 2011. URL: http://www.calameo.com/ $\mathrm{read} / 000075335 \mathrm{cl} 84 \mathrm{bd} 7 \mathrm{c} 7 \mathrm{~b} 68>$ 